\title{
KATA TANYA DALAM KONSTRUKSI INTEROGATIF BAHASA MANDAILING
}

\author{
Rodiyah Harahap, Mulyadi
}

Surel: rodiyahhrp@gmail.com

\begin{abstract}
ABSTRACK
This study discusses the polar interrogative construction in Mandailing. This study aims to analyze the form of interrogative in Mandailing. The research data is a mandailing sentence that comes from related literature on interrogative. This research employs questions words which of the thoughts of foreign and Indonesian linguists. The research method used is descriptive method which employs substitution, permutation, and reference techniques. The result of this research shows that: Question words as interrogative markers can indicate different interrogative contruction types.
\end{abstract}

Keywords: question words, interrogative construction, rhetoric interrogative

\begin{abstract}
ABSTRAK
Penelitian ini membahas tentang kata tanya dalam konstruksi interogatif pada Bahasa Mandailing. Penelitian ini bertujuan untuk menganalisis kata tanya dari setiap tipe introgatif. Data penelitian berupa kalimat bahasa Mandailing yang bersumber dari literatur yang berkaitan tentang konstruksi interogatif. Teori yang digunakan dalam penelitian ini adalah teori kalimat tanya dari para pakar linguistik. Metode penelitian yang digunakan dalam penelitian ini adalah metode deskriptif dengan menggunakan teknik ganti, teknik balik, dan teknik acuan (referensi). Hasil penelitian ini menunjukkan kata tanya sebagai alat pembentuk kalimat interogatif dapat menandai perbedaan tipe konstruksi interogatif.
\end{abstract}

Kata Kunci: Kata Tanya, Konstruksi Interogatif, Interogatif Retorik, Bahasa Mandailing

\section{PENDAHULUAN}

Konstruksi introgatif menurut ahli bahasa Indonesia umumnya terbagi kedalam tiga tipe yaitu interogatif terbuka, interogatif tertutup, dan interogatif retorik. Pemerolehan informasi sangatlah penting bagi kehidupan manusia. Bagaimana informasi itu sampai kepada manusia dapat diungkapkan melalui bahasa. Semua bahasa mempunyai cara khusus untuk menyampaikan informasi. Penyampaian informasi dapat dilakukan melalui pertanyaan. Dalam ilmu bahasa bentuk pertanyaan itu berkaitan dengan perihal konstruksi interogatif. Konstruksi interogatif dapat dibentuk di antaranya oleh indikator berupa kata tanya. Sebagai pembentuk kalimat interogatif, kata tanya perlu mendapat perhatian khusus. Dengan kata tanya, perbedaan tipe interogatif dapat diketahui. Sebagai contoh dapat dikemukakan bahwa kata tanya apa dapat menandai perbedaan setiap tipe interogatif baik secara sintaktis maupun secara semantik dalam bahasa mandailing sebagai contoh dapat dikemukakan bahwa kata 
tanya apa dalam bahasa mandailing dapat menandai perbedaan setiap

a. $\frac{\text { Aha do karejomu? }}{\mathrm{O}(\mathrm{FN})(\text { part })(\mathrm{SN}) \quad \mathrm{P}(\mathrm{N})}$

Apa yang kamu kerjakan?

b. Ise donganmu kini maridi?

Siapa kawanmu tadi mandi ?
c. Pintu do na sego i ? $\mathrm{S}+\mathrm{PRP}+\mathrm{P}$

Pintukah yang rusak itu?

d. Aha ma na didongkon halak anon? (Interogatif retorik) FN

Apa kata orang nanti ?

Secara sintaktis, kata tanya apa dalam kalimat (1) dan (2) dapat mengisi fungsi sintaksis, sedangkan dalam kalimat (3) dan (4) kata tanya apa tidak mengisi fungsi sintaksis. Selain itu, kata tanya apa dalam kalimat-kalimat tersebut memiliki pola urutan yang berbeda. Kata tanya apa pada kalimat (1), (3), dan (4) terletak di posisi awal kalimat; pada kalimat (2) kata tanya apa terletak di posisi akhir kalimat. Struktur kata tanya apa pada kalimat-kalimat di atas pun berbeda, kata tanya apa pada kalimat (1), (3), dan (4) merupakan konstituen kata, sedangkan kata tanya apa pada kalimat (2) merupakan konstituen frasa. Secara semantis, pertanyaan yang disampaikan dalam kalimat (1) dan (2) berisikan informasi baru, sedangkan kalimat (3) dan (4) berisikan informasi lama. tipe interogatif baik secara sintaktis maupun secara semantis.

(interogatif terbuka)

(interogatif terbuka)

(interofatif tertutup)
Bagaimana dengan kata tanya lainnya, seperti kata tanya siapa, berapa, mengapa, kenapa, mana, di mana, ke mana, dari mana, dan bagaimana.

Pembahasan perilaku sintaktis kata tanya yang menandai atau membentuk setiap tipe interogatif dalam artikel ini mencakup (i) fungsi sintaksis yang dapat mengisi kata tanya, (ii) pola urutan kata tanya yang dapat membedakan tipe interogatif, dan (iii) korelasi kata tanya dengan konstituen lain, yakni kata, frasa, dan klausa dalam setiap tipe interogatif. Pembahasan secara semantis mencakup informasi apa yang disampaikan dalam setiap tipe interogatif. Selain itu, kata tanya ada yang berperan sebagai alat untuk bertanya dan ada pula kata tanya yang tidak digunakan untuk bertanya. Pada umumnya, tipe 
interogatif dibagi menjadi dua, yaitu tipe interogatif tertutup atau polar interrogative dan interogatif terbuka atau open interrogative. Sebagian pakar bahasa lainnya, memasukkan pula tipe interogatif alternatif dan tipe pertanyaan yang bersifat retorik. Sementara itu, pakar bahasa Indonesia umumnya membagi interogatif menjadi dua bentuk, yaitu (i) bentuk kalimat yang digunakan untuk mengungkapkan pertanyaan dengan jawaban ya/tidak dan (ii) bentuk kalimat yang digunakan untuk mengungkapkan pertanyaan dengan jawaban berupa informasi (Simud, 2001:79).

Ramlan, (1981:

mengemukakan bahwa kalimat tanya pada umumnya berfungsi untuk menanyakan sesuatu. Kalimat tanya memiliki nada akhir lebih tinggi dari kalimat berita. Nada akhir itu dituliskan dengan tanda tanya. Penambahan kata tanya dalam kalimat tanya cenderung diletakkan di awal kalimat. Chaer (2000: 350) menyatakan bahwa kalimat tanya adalah kalimat yang isinya mengharapkan reaksi atau jawaban berupa pengakuan, keterangan, alasan atau pendapat dari pihak pendengar atau pembaca.

Ciri-Ciri Kalimat Tanya (Alisyahbana:1983:79)

a. Selalu di akhiri dengan tanda baca yaitu tanda tanya (?)

b. Pada umumnya diawali dengan kata-kata tanya seperti apa, siapa, kapan, dimana, mengapa, dan bagaimana. c. Sering juga disertai dengan imbuhan -kah, dan partikel kan contohnya apakah, dimanakah?, kapankah?, ya kan? dan lain-lain.

d. Memiliki dua macam intonasi, yaitu pada kalimat tanya yang hanya membutuhkan jawaban ya atau tidak, intonasi pada akhir kalimat naik. Sedangkan pada kalimat tanya yang membutuhkan jawaban yang jelas, intonasi pada akhir kalimat menurun.

Apakah kamu sudah makan?

Madung mangan ho?

(Intonasi menaik pada kata ho)

Dimana kamu bertemu dengan Sutar?

(Intonasi menurun pada kata Andi)

Didia hamu marsuo dohot si Sutar?

Tipe Interogatif

Tipe Introgatif

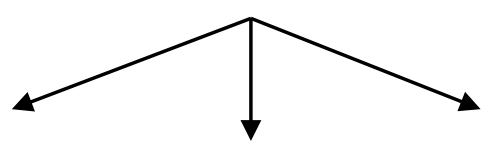

Terbuka Tertutup Retorik

a. Introgatif Terbuka

- Apa, siapa, mengapa kenapa, berapa, mana, di mana, dari mana, ke mana, dan bagaimana.

- Secara umum berisi informasi baru

- Dapat menjadi konstituen kata dan konstituen frasa. 
- Sebagai konstituen kata memiliki pola urutan yang tidak terikat di dalam kalimat.

- Dapat bergabung dengan kategori sintaktis berupa kata, frasa, dan klausa; kata tanya dapat mengisi salah satu fungsi sintaksis, S, P, O, Pel, dan Ket.

b. Introgatif Tertutup

- Apa, apakah, dan bagaimana

- Letak urutan kata tanya di dalam kalimat cenderung menempati posisi di depan atau di awal kalimat.

- Kata tanya tidak mengisi atau menggantikan fungsi sintaksis. Oleh karena itu pelesapan kata tanya dengan intonasi tertentu dapat dilakukan tanpa mengubah informasi yang ditanyakan.

- Secara umum berisi informasi lama.

c. Introgatif Retorik

- Secara sintaktis konstruksi interogatif retorik memiliki struktur yang sama dengan konstruksi interogatif terbuka dan konstruksi interogatif tertutup.

- Pemarkah tanya dalam tipe interogatif tidak digunakan untuk bertanya.

- Secara semantis dalam tipe interogatif retorik terdapat beragam makna.
Teknik balik digunakan untuk menentukan kata tanya sebagai konstituen kata atau sebagai konstituen frasa. Kata tanya sebagai konstituen kata memiliki letak urutan yang tidak terikat, perubahan atau pemindahan letak urutan kata tanya tidak menyebabkan perubahan tipe interogatif. Hal ini dapat dilihat pada kalimat (6) berikut ini.

\section{d. Aha ma na diboto ho} simanjungjung?

\section{FN}

Apa yang kau tau tentang simanjunjung?

e. Na diboto ho simanjungjung $i$ aha?

FN

yang kau tentang simanjunjung apa?

Perubahan letak kata tanya apa menjadi di akhir kalimat pada contoh kalimat $f$ tidak menyebabkan perubahan tipe konstruksi interogatif maka kata tanya apa dalam kalimat $\mathrm{f}$ berfungsi sebagai konstituen kata. Selanjutnya, kata tanya sebagai konstituen frasa memiliki letak urutan yangterikat dengan konstituen yang berada di sampingnya. Perubahan atau pemindahan salah satu unsurnya menyebabkan kalimat tidak gramatikal atau menyebabkan adanya perubahan tipe interogatif. Hal ini dapat dilihat pada kalimat berikut: 
Rodiyah Harahap, Mulyadi: Kata Tanya Dalam...

e. Songon aha anak i ?

Fadv

FN

Seperti apa anak itu ?

f. * Seperti ... bayi itu apa ?

Songon ....anak I aha?

g. *Apa Seperti ... bayi itu

Aha

Songon......anak i

Teknik acuan atau teknik referensial digunakan untuk menentukan informasi yang disampaikan dalam konstruksi interogatif apakah berupa informasi lama atau informasi baru.

h. Aha na markumpul disadun?

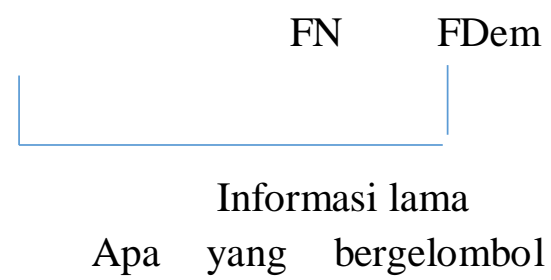
disana?

i. Aha rancanamu?

FN

Informasi baru

Apa rencana kamu?

\section{METODE PENELITIAN}

Metode penelitian yang diterapkan dalam penelitian ini adalah metode deskriptif yang erat hubungannya dengan metode kualitatif dan ciri latar alami. Metode deskriptif digunakan dengan pertimbangan bahwa penelitian ini memusatkan perhatian pada ciri-ciri dan sifat bahasa secara alami (natural language) serta kenyataan bahasa apa adanya yang secara empiris masih hidup dalam pemakaian bahasa yang bersangkutan.

Cara kerja yang bersistem di dalam penelitian bahasa yang bertolak dari data yang dikumpulkan secara deskriptif ini menggunakan metode distribusional dengan teknik sulih dan teknik balik serta metode padan dengan teknik referensial. Teknik sulih (subtitusi) digunakan untuk mengetahui kategori apa saja yang dapat bergabung dengan kata tanya dalam konstruksi interogatif.

\section{HASIL PENELITIAN DAN PEMBAHASAN}

Kata tanya dalam konstruksi interogatif terbuka adalah apa, siapa, mengapa kenapa, berapa, mana, di mana, dari mana, ke mana, dan bagaimana. Kata-kata tanya tersebut dapat menjadi konstituen kata dan konstituen frasa. Kata tanya sebagai konstituen kata memiliki pola urutan yang tidak terikat di dalam kalimat. Kata tanya dapat bergabung dengan kategori sintaktis berupa kata, frasa, dan klausa; kata tanya dapat mengisi salah satu fungsi sintaksis, S, P, O, Pel, dan Ket.

a. Isede na giot kehetu Medan i ?
S (part)
(P)
(Ket) 
Siapa yang mau pergi ke Medan itu

*.........Na giot kehe i ?

Yang mau pergi itu?

Na giot kehe I ise ?

Yang ingin pergi tu siapa?

b. Umak-umak perlu aha?

$$
\mathrm{S} \quad(\mathrm{P}) \quad \mathrm{Pel}
$$

*umak- umak perlu......?

Perlu aha Umak-umak?

Umak-umak ahana perlu?

(interogatif tertutup)

c. Aha sebabna ho margoyak

$$
\text { Ket } S
$$

roha tu si Datun?

$\mathrm{P} \quad \mathrm{O}$

Apa sebabnya ku membenci Datun?

*... sebab ho margoyak roha tu si Datun?

Sebab kau membenci Datun?

Ho margoyak roha tu si Datun aha sebana?

Kau membenci si Datun apa sebabnya?

Aha sebab ho margoyak roha tu si Datun?

Sebab apa kau membenci Datun ?

Pada kalimat a kata taya apa sebagai konstituen kata mengisi fungsi $\mathrm{S}$ yang berkorelasi dengan FN na giot kehetu Medan i, sedangkan pada kalimat $\mathrm{b}$ dan $\mathrm{c}$ kata tanya aha sebagai konstituen frasa mengisi fungsi d Pel dan fungsi Ket yang masing-masing berkorelasi dengan FN umak-umak dan KL kau margoyak Datun. Informasi yang disampaikan pada kalimat a dan c berupa informasi lama. Pada kalimat a, informasi lama secara eksplisit ditandai oleh konstituen berupa FDem di sana itu, sedangkan pada kalimat c informasi lama ditandai oleh konteks kalimat yang merujuk pada kejadian sebelumnya. Informasi yang disampaikan pada kalimat $b$ berupa informasi baru.Selanjutnya, sebagai contoh lain adalah penggunaan kata tanya ise, mangua, sadia dapat dilihat berikut ini.

d. Ise de i?

$$
\begin{array}{ll}
\mathrm{P} & (\mathrm{S}) \\
\mathrm{FN} & (\mathrm{N})
\end{array}
$$$$
\text { IB }
$$

Siapa dia ?

*......de i?

I de ise ?

e. Mangua ho ro ?

Ket $\mathrm{O} P$

Kenapa kau datang ?

f. Mangua baru sonnari kasus i ro ?

Ket (Ket) (S) (p)

IL

KL

Kenapa baru sekarang kasus itu datang ?

g. Sadia anak bapak?

$\mathrm{P} \quad(\mathrm{S})$

Num (FN)

Berapa anak bapak ?

Anak bapak sadia?

h. Nak giot pasuo dohot ise ?
(S)
(P) Ket 
Rodiyah Harahap, Mulyadi: Kata Tanya Dalam...

(N)

(FV)

FPrep

KL

IB

*Nak giot pasuo dohot .....?

Nak mau bertemu siapa?

*dohot ise nang giot pasuo ?

Dengan siapa nak ingin pasuo?

i. Sadia kilometer $i$ ?

$\mathrm{P}$

FN

(Dem)

IL

*Sadia i Kilometer na ?

Berapa itu kilometernya?

*Kilometer sadia i?

(perubahan makna)

Pada kalimat d, kata tanya ise sebagai konstituen kata mengisi fungsi $\mathrm{P}$ berkorelasi dengan $\mathrm{N}$ dia; pada kalimat e kata tanya mengapa sebagai konstituen kata mengisi fungsi Ket berkorelasi dengan KL mangua ho ro...; pada kalimat $\mathrm{f}$ kata tanya mangua sebagai konstituen kata mengisi fungsi Ket berkorelasi dengan KL ro 'datang'; pada kalimat g kata tanya berapa sebagai konstituen kata mengisi fungsi $\mathrm{P}$ berkorelasi dengan FN anak bapak; pada kalimat $\mathrm{h}$ kata tanya dengan ise sebagai konstituen frasa mengisi fungsi P berkorelasi dengan KL nak ingin pasuo; pada kalimat ikata tanya berapa kilometer sebagai konstituen frasa mengisi fungsi $\mathrm{P}$ berkorelasi dengan Dem itu. Informasi yang disampaikan pada kalimat d, g, dan h berupa informasi baru, sedangkan pada kalimat e, f, dan $\mathrm{i}$ berupa informasi lama.
Demikian halnya dengan kata tanya mana, dari mana, di mana, ke mana, dan bagaimana, penggunaannya dalam kalimat ada yang menjadi konstituen kata dan konstituen frasa. Kata tanya tersebut dapat berkorelasi dengan kategori sintaktis berupa kata, frasa, dan klausa dan juga dapat mengisi fungsi sintaksis di antaranya, fungsi S, P, O, Pel, dan Ket. Oleh karena itu, kata tanya dalam konstruksi interogatif terbuka kehadirannya wajib ada atau tidak dapat dilesapkan.

Dalam konstruksi interogatif tertutup hanya ditemukan tiga kata tanya, yaitukata atanya apa, apakah, dan bagaimana. Letak urutan kata tanya di dalam kalimat cenderung menempati posisi di depan atau di awal kalimat. Kata tanya dalam konstruksi interogatif tertutup tidak mengisi atau menggantikan fungsi sintaksis. Oleh karena itu, pelesapan kata tanya dengan intonasi tertentu dapat dilakukan tanpa mengubah informasi yang ditanyakan. Contoh analisis penggunaan kata tanya dalam konstruksi interogatif tertutupdapat dilihat pada paparan berikut ini.

a. Aha salah ku?

$\mathrm{KL}$ (S) (P)

IB

(apa salah ku )

.....Au alah?

(aku salah ?)

Au salah aha?

(tipe intergatif tertutup) 
b. Salolot on au malehen harapan?

$\mathrm{KL}$
(Ket)
(s) $(\mathrm{P})$
(O)

...Salolot on au malehen harapan?

Salolotnon au malehen harapan?

Salolot on au malehen aha?

c. aha ho mandongani ia juo?

(S) (P)

(Pel)

Apa kau yang mengawani dia juga ....ho biasa mandongani ia juo?

Kau bisa ngawani dia juga?

Ho bisa mandongani ia juo?

Ho bias mandongani iya, aha?

Kau bisa ngawani dia ,apa?

d. Porlu dope hupiyo si halim?
FADv
FV

Perlu lagi aku manggil halim?

....Porlu hu piyo si halim?

Perlu aku panggil si halim

Hupiyo si halim perlu dope?

Ku panggil si halim perlu lagi?

Pada kalimat a, b, dan c kata tanya sebagai konstituen kata berkorelasi dengan kategori sintaktis berupa KL saya salah, KL salolot on au malehen harapan, dan KL kamu bisa menemui dia juga. Kata tanya sebagai konstituen kata memiliki letak urutan yang tidak terikat, sehingga letak urutan di dalam kalimat dipindahkan, kecuali untuk kata tanya apakah yang tidak dapat menempati posisi di akhir kalimat. Pada kalimat d kata tanya apa berbentuk sebagai konstituen frasa yang berkorelasi dengan kategori sintaktis FV hupiyo si Halim. Informasi yang disampaikan pada kalimat a berupa informasi baru, sedangkan informasi yang disampaikan pada kalimat b, c, dan d berupa informasi lama.Pada kalimat b informasi lama secara eksplisit ditandai oleh konstituen FAdv selama ini, sedangkan pada kalimat $\mathrm{c}$ dan $\mathrm{d}$ informasi lama ditandai oleh konteks kalimat yang merujuk pada kejadian sebelumnya.

Selanjutnya penggunaan kata tanya bagaimana dalam konstruksi interogatif tertutup dapat dilihat pada contoh kalimat berikut ini :

e. Biade, setuju?

$\mathrm{N}$

Bagaimana setuju ?

......Setuju?

Setuju Biadehe ?

(Interogatif terbuka )

Setuju bagaimana?

Secara leksikal kata tanya bagaimana pada kalimat e digunakan untukmenanyakan keadaan dengan jawaban yang diharapkan berupa informasi tertentu. Penggunaan kata tanya bagaimana dalam konstruksi interogatit tertutup padadasarnya terjadi karena adanya pelesapan kata tanya apa atau apakah sebagaialat interogatif tertutup, sehingga kalimat e berasal dari konstruksi interogatif sebagai berikut.

Bagaimana, $\left\{\begin{array}{l}\text { Aha } \\ \text { (apa) }\end{array}\right\}^{\text {Setuju? }}$ 
Konstruksi interogatif retorik memiliki kesamaan dengan konstruksi interogatif terbuka dan konstruksi interogatif tertutup. Dalam beberapa hal tertentu, secara sintaktis konstruksi interogatif retorik juga memiliki struktur yang sama dengan konstruksi interogatif terbuka dan konstruksi interogatif tertutup. Akan tetapi, secara semantis dalam tipe interogatif retorik terdapat beragam makna di antaranya terdapat makna imperatif, deklaratif, dan eksklamatif. Pemarkah Tanya dalam tipe interogatif tidak digunakan untuk bertanya. Informasi yang disampaikan keseluruhannya berisi informasi lama. Isi pertanyaan bersifat pragmatis, sehingga makna yang muncul berbeda bergantung pada konteks kalimat yang dimaksud. Contoh-contoh kalimat berikut ini adalah konstruksi interogatif retorik dalam bahasa mandailing secara formal ditandai oleh kata tanya: aha, ise, mangua, aso.

\section{a. Aha didongkon halak anno}

FN

Apa yang akan dikatakan orang nanti

Makna deklaratif

\section{b. Alah mimpi aha au}

Fts FN

Aduh mimpi apa aku

Makna eksklamatif c. Aha susah na manelepon

FN V

Apa susahnya menelepon

Penggunaan kata tanya apa pada contoh kalimat a sebagai konstituen kata bergabung dengan FN didongkon halak anno. Kata tanya apa pada contoh kalimat $\mathrm{b}$ dan c sebagai konstituen frasa bergabung dengan kategori sintaktis berupa kategori Fts ya dan kategori $\mathrm{V}$ menelpon. Secara semantis, makna kalimat a merupakan makna deklaratif, makna b merupakan makna eksklamatif, dan makna kalimat c merupakan makna imperatif. Selanjutnya penggunaan kata tanya apakah dalam konstruksi interogatif retorik dapat dilihat pada contoh kalimat $\mathrm{d}$ berikut.

\section{d. Manjalaki ilmu sesuatu \\ FV \\ masalah}

Mencari ilmu suatu masalah?

Makna deklaratif

Kata tanya pada kalimat d merupakan konstituen kata yang bergabung dengan FV mencari ilmu sesuatu yang salah. Secara sintaktis, penggunaan kata tanya apakah dalam konstruksi interogatif retorik memiliki struktur yang hampir sama dengan konstruksi interogatif tertutup, yaitu kata Tanya apakah dapat bergabung dengan kategori sintaktis berupa kata, frasa, dan klausa. 


\section{SIMPULAN}

Kata tanya merupakan salah satu alat formal yang menandai konstruksi interogatif. Konstruksi interogatif adalah konstruksi yang dibentuk oleh konstituen-konstituen berupa kata tanya yang berkorelasi dengan kategori gramatikal kata, frasa, dan klausa. Simpulan mengenai penggunaan kata tanya dalam konstruksi interogatif bahasa Mandailing secara sebagai alat pembentuk kalimat interogatif dapat menandai perbedaan tipe konstruksi interogatif bahasa Mandailing, yakni tipe interogatif terbuka, interogatif tertutup, dan interogatif retorik.

Kata tanya memiliki ciri-ciri sintaktis yang berbeda dalam setiap tipe interogatif. Dalam tipe interogatif terbuka, kata tanya ada yang menjadi sebagai konstituen kata dan sebagai konstituen frasa yang masing-masing dapat bergabung dengan kategori sintaktis berupa kata, frasa, dan klausa. Kata tanya sebagai konstituen kata memiliki pola urutan yang tidak terikat di dalam kalimat. Kata tanya sebagai konstituen kata dan sebagai konstituen frasa dalam tipe interogatif terbuka dapat mengisi fungsi sintaksis. Dalam tipe interogatif tertutup kata tanya cenderung menjadi sebagai konstituen kata. Kata tanya dalam konstruksi interogatif tertutup tidak mengisi fungsi sintaksis. Kata tanya sebagai konstituen kata dan sebagai konstituen frasa dalam konstruksi interogatif retorik selalu menjadi bagian dari kalimat dan hubungannya sangat erat dengan konstituen lainnya, sehingga letak urutan kata tanya dalam kalimat tidak dapat diubah atau dipindahkan.

\section{DAFTAR RUJUKAN}

Alisyahbana, S.T. 1983. Tata Bahasa Baru Jilid I. Jakarta: Dian Rakyat.

Chaer, Abdul. 2000. Tata Bahasa Praktis Bahasa Indonesia (Edisi Revisi). Jakarta: Rineka Cipta.

Lubis, Masdiana. 2002. Kalimat Tanya dalam Bahasa Mandailing: Analisis Sintaksis. (Skripsi). Medan: Sekolah Pasca Sarjana USU.
Ramlan.
1981.
Sintaksis. Yogyakarta: Karyono.

Siemund, Peter. 2001. Interrogative Constructions. Berlin: Mouton de Gruyter. 